\title{
ANALISIS HUBUNGAN PELAKSANAAN PROMOSI KESEHATAN DENGAN KUNJUNGAN IBU BALITA KE POSYANDU DI PUSKESMAS NANGGALO DAN PUSKESMAS LUBUK BUAYA KOTA PADANG TAHUN 2015
}

\author{
Relationship Analysis of Implementation of Health Promotion With Mother Visit to \\ Posyandu in Puskesmas Nanggalo and Puskesmas Cultural Powder of Padang City 2015
}

\author{
Hilda Hidayat
}

\author{
Dosen Tetap Fakultas Kesehatan Masyarakat - Universitas Biturrahmah Padang \\ Email : hildahidayat15@gmail.com
}

\begin{abstract}
Abstrak
Pelaksanaan Promosi Kesehatan (Promkes) sangat penting meningkatkan kunjungan ibu balita ke posyandu. Namun, proses perubahan perilaku ibu balita tidaklah mudah. Puskesmas Nanggalo memiliki tingkat kunjungan ibu balita terendah $(43,2 \%)$ dan tertinggi $(77,1 \%)$ di Puskesmas Lubuk Buaya dari target 80\%. Penelitian ini dilaksanakan bulan Februari sampai Agustus 2015 dan menggunakan metode kualitatif di Puskesmas Nanggalo dan Lubuk Buaya Kota Padang. Pengumpulan data dengan wawancara mendalam (6 informan), telaah dokumen dan observasi. Pengolahan data dengan triangulasi. Di kedua puskesmas belum ada petunjuk teknis, sumber dana Anggaran Pendapatan Belanja Daerah (APBD) dan Biaya Operasional Kesehatan (BOK). Di Puskesmas Nanggalo, petugas promkes sebagai pelaksana posyandu, sedangkan Puskesmas Lubuk Buaya petugas sebagai pengkoordinir kegiatan. Posyandu Lubuk Buaya menetap di rumah warga dan sarana sudah tersedia, sedangkan di Nanggalo belum ada. Kemitraan dan pemberdayaan Puskesmas Lubuk Buaya berjalan baik dibandingkan Puskesmas Nanggalo sehingga tingkat kunjungan ibu balita hampir mencapai target. Puskesmas membuat petunjuk teknis dan Surat Keputusan (SK), mengadakan pelatihan untuk pelayanan posyandu, dan buku pedoman.
\end{abstract}

Kata kunci : Pelaksanaan Promosi kesehatan (Advokasi, Kemitraan, Gerakan Pemberdayaan), Kunjungan Ibu Balita ke Posyandu

\begin{abstract}
The role of health promotion is very important in anticipating the behavior of the public to know, willing and able to mobilize mothers to Posyandu. But, the process of behavioral change in society is not easy, it is seen at the Nanggalo Health Center which has a rate visit new mothers to Posyandu is 43.2\% and highest $77.1 \%$ in Puskesmas Lubuk Buaya with a target of $80 \%$. The research has done in February until August 2015 was conducted using qualitative research methods, the research location in Nanggalo Health Center and Lubuk Buaya Health Centre in Padang City. The qualitative data was collected using interview guideline to 6 informants, document analysis and observation. Qualitative data processing by triangulation. At Nanggalo and Lubuk Buaya Health Centre there is no technical rule, financial resources, and Region Budget Income and Health Operational Financial. At Nanggalo Health Centre, Health Promotion Officer as posyandu officer, and then at Lubuk Buaya Health Centre Health Promotion Officer as activity coordinator. Lubuk Buaya Posyandu stay at citizen home and facilities are available but in Nanggalo hasn't. Partnership and empowerement Lubuk Buaya Health Centre run as expected compare Nanggalo Health Centre cause of that the mother to visit posyandu almost reach of target. Health Centre make technical rule and decision letter to hold posyandu training, and health promotion manual direction.
\end{abstract}

Keywords : Analysis Health Promotion (Advocacy, Partnership, Community Empowerment), Visit Mother Toddler

\section{PENDAHULUAN}

Pelaksanaan Promosi Kesehatan (Promkes) sangat penting meningkatkan kunjungan ibu balita ke posyandu. Namun, proses perubahan perilaku ibu balita tidaklah mudah, hal ini terlihat di
Puskesmas Nanggalo yang mempunyai tingkat kunjungan ibu balita terendah (43,2\%) dan Puskesmas Lubuk Buaya dengan tingkat kunjungan ibu balita tertinggi $(77,1 \%)$ dari target $80 \%$ (Laporan DKK Padang, 2014). 
Penelitian ini menggunakan metode kualitatif, di Puskesmas Nanggalo dan Lubuk Buaya Kota Padang dan dilaksanakan Februari sampai Agustus 2015. Pengumpulan data dengan wawancara mendalam (6 informan), telaah dokumen dan observasi. Validitas data dengan metode triangulasi. Di Puskesmas Nanggalo dan Puskesmas Lubuk Buaya didapatkan belum ada petunjuk teknis, sumber dana dari Anggaran Pendapatan Belanja Daerah (APBD) dan Biaya Operasional Kesehatan (BOK).

Di Puskesmas Nanggalo, petugas promkes sebagai pelaksana posyandu, sedangkan di Puskesmas Lubuk Buaya petugas promkes sebagai pengkoordinir kegiatan. Prasarana (tempat posyandu menumpang di rumah warga atau mesjid) dan sarana (timbangan belum dikalibrasi serta poster, leafleat, PMT) tidak ada di Puskesmas Nanggalo sedangkan di Puskesmas Lubuk Buaya prasarana menetap di rumah warga dan sarana seperti di atas sudah tersedia di posyandu. Kemitraan dan pemberdayaan Puskesmas Lubuk Buaya berjalan dengan baik dibandingkan Puskesmas Nanggalo sehingga tingkat kunjungan ibu balita hampir mencapai target.

Penelitian ini bertujuan untuk mengetahui pelaksanaan promosi kesehatan (advokasi, kemitraan, pemberdayaan) dan dengan kunjungan ibu balita ke posyandu di Puskesmas Nanggalo dan petunjuk teknis, Sumber Daya Manusia (SDM), dana, metode, sarana serta tingkat kunjungan ibu balita ke posyandu di Puskesmas Nanggalo dan Puskesmas Lubuk Buaya Kota Padang.

\section{METODE PENELITIAN}

Penelitian ini menggunakan metode kualitatif dengan rancangan penelitian studi kebijakan untuk menggali informasi mendalam dalam pelaksanaan promkes terhadap kunjungan ibu balita ke posyandu. Informan penelitian adalah Kepala Puskesmas Nanggalo dan Lubuk Buaya, Petugas pemegang program promkes Puskesmas Nanggalo dan Lubuk Buaya, Lurah Kurao Pagang dan Lubuk Buaya, Kader di Kelurahan Kurao Pagang dan Lubuk Buaya, Ibu balita di wilayah kerja Puskesmas Nanggalo dan Puskesmas Lubuk Buaya. Alat yang digunakan pedoman wawancara mendalam, daftar telaah dokumen, catatan lapangan serta tape recorder. Aktifitas dalam analisis data meliputi reduksi data, penyajian data dan pengambilan keputusan.

\section{HASIL PENELITIAN}

Hasil pengumpulan data di Puskesmas Nanggalo dan Puskesmas Lubuk Buaya berdasarkan telaah dokumen, observasi dan wawancara mendalam tentang :

1. Petunjuk teknis

Analisis triangulasi tentang petunjuk teknis pelaksanaan promkes di kedua puskesmas bahwa belum ada (merupakan pelayanan dasar puskesmas). Pernyataan ini benar, dibuktikan : tidak ditemukan aturan dan petunjuk teknis pelaksanaan promkes.

2. Sumber Daya Manusia (SDM)

Analisis triangulasi tentang SDM pelaksanaan promkes di Puskesmas Nanggalo bahwa Sumber Daya Manusia (SDM) yang bertanggung jawab dalam pelaksanaan promkes hanya 1 orang sebagai koordinator program promkes. Seharusnya minimal ada 2 orang tenaga promkes di puskesmas dan koordinator program hanya mengkoordinir dan memfasilitasi kegiatan. Sedangkan di Puskesmas Lubuk Buaya, petugas pemegang program promkes sudah bertindak sebagai pengkoordinir kegiatan pelaksanaan promkes di puskesmas.

3. Pendanaan promkes di kedua puskesmas berasal dari dana Anggaran Pengeluaran Belanja Daerah (APBD), dana Bantuan Operasional Kesehatan (BOK), Program Nasional Pemberdayaan Masyarakat (PNPM).

4. Metode promosi kesehatan yang dilakukan di kedua puskesmas yaitu dengan Pemberian Makanan Tambahan (PMT), dan memperkuat peran aktif Toma, Tim Penggerak PKK, dan Lurah menggerakkan posyandu. 


\section{PEMBAHASAN}

Berdasarkan hasil penelitian yang peneliti lakukan di Puskesmas Nanggalo dan Puskesmas Lubuk Buaya tentang pelaksanaan promkes terhadap kunjungan ibu balita ke posyandu, bahwa :

\section{Petunjuk Teknis}

Petunjuk teknis di kedua puskesmas belum ada dan tidak ada dituangkan dalam Surat Keputusan (SK) pelaksana promkes sehingga siapa-siapa yang bertanggung jawab sesuai dengan tugas dan fungsinya tidak menjalankan kewajibannya dengan baik.

Di Puskesmas Nanggalo, petunjuk teknis promkes berupa kegiatan sosialisasi dan pemberitahuan pelaksanaan kegiatan posyandu saja. Padahal jika dikaji promkes erat kaitannya dengan upaya pemberdayaan masyarakat agar mau dan mampu serta mandiri dalam melindungi kesehatan diri dan lingkungannya, dengan membangkitkan kesadaran akan potensi yang dimiliki serta menciptakan iklim untuk berkembang dalam memelihara dan meningkatkan kesehatan.

Di Puskesmas Lubuk Buaya, pemegang program promkes dan SDM yang terlibat memotivasi ibu balita ke posyandu serta melakukan tugas dengan penuh rasa tanggung jawab berdasarkan standar pelayanan minimal.

Menurut Green dalam Notoatmodjo (2007), salah satu faktor penguat (reinforching) yang mempunyai peranan penting untuk merubah perilaku yaitu adanya aturan yang jelas dan mengikat pelaksananya (dituangkan dalam bentuk SK)

Menurut Penelitian Sucipto (2009) bahwa adanya kebijakan promkes dapat berperan dalam praktik peningkatan kunjungan ibu balita ke posyandu. Peran promkes yang dijalankan ada pada seluruh sektor misalnya : lurah, toma, kader dan petugas puskesmas.

Oleh karena itu berdasarkan analisis peneliti perlu adanya petunjuk teknis yang menjelaskan peran dan fungsi tenaga pelaksana promkes yang dituangkan pada Surat Keputusan (SK) tentang tugas dan tanggung jawabnya memotivasi ibu balita ke posyandu. Karena pada dasarnya setiap aturan / petunjuk teknis yang dituangkan pada SK akan memicu semangat dan mengikat SDM yang terlibat untuk menggerakkan posyandu. Misalnya aturan tentang petunjuk teknis pelaksanaan promkes terkait cara advokasi, kemitraan dan gerakan pemberdayaan masyarakat yang dilakukan oleh pimpinan puskesmas, lurah, tenaga kesehatan/pemegang program promkes, kader dan Toma.

\section{Sumber Daya Manusia (SDM)}

Hasil penelitian diketahui bahwa SDM yang terlibat di kedua puskesmas adalah petugas kesehatan. Petugas kesehatan puskesmas seharusnya hanya mengkoordinir kegiatan promkes dan berjumlah minimal 2 orang sebagai penanggung jawab kegiatan. Sedangkan di Puskesmas Nanggalo petugas promkes terjun langsung dalam memotivasi ibu balita ke posyandu dan melakukan penyuluhan pada hari posyandu. Di Puskesmas Lubuk Buaya, petugas promkes hanya mengkoordinir kegiatan promkes di puskesmas dan tidak terjun langsung pada hari posyandu.

Hasil penelitian Sucipto (2009) menyatakan bahwa tenaga yang membantu dalam promkes untuk meningkatkan kunjungan ibu balita ke posyandu merupakan hal yang dibutuhkan. Namun kenyataannya pandangan masyarakat menyatakan posyandu hanya milik puskesmas. Padahal posyandu merupakan unit pelayanan terdepan yang berada pada tingkat kelurahan/desa dan yang bertanggung jawab adalah lurah, toma, dan tim penggerak PKK.

Peran dan dukungan lurah, toma dan tim penggerak PKK merupakan hal yang sangat penting dalam pelaksanaan promkes terhadap kunjungan ibu balita ke posyandu. Peran petugas kesehatan sebagai pelaksana program harus diikuti oleh peran dan tanggung jawab dari tokoh masyarakat untuk menggerakkan ibu balita guna memantau tumbuh kembang balitanya ke posyandu.

\section{Dana}

Hasil penelitian diketahui bahwa pendanaan dalam pelaksanaan promkes untuk peningkatan kunjungan ibu balita ke posyandu berasal dari dana Anggaran 
Pengeluaran Belanja Daerah (APBD), dana Bantuan Operasional Kesehatan (BOK), Program Nasional Pemberdayaan Masyarakat (PNPM) yang digunakan untuk honor kader dan penggantian transport kader, namun jumlahnya tidak mencukupi.

Hasil penelitian ini sesuai dengan penelitian yang dilakukan oleh Sucipto (2009) yang menyatakan bahwa adanya dana dalam promkes dapat berperan dalam peningkatan kunjungan ibu balita ke posyandu. Peran promkes yang dijalankan ada pada seluruh sektor yang terlibat dalam pelayanan posyandu yaitu petugas puskesmas, toma dan kader posyandu harus didukung oleh pendanaan sehingga petugas memiliki motivasi dalam pelaksanaan kegiatan.

Menurut Green dalam Notoatmodjo (2007), salah satu faktor pemungkin (enabling) yang mempunyai peranan penting untuk merubah perilaku yaitu tersedianya biaya. Biaya atau dana ini adalah salah satu faktor yang mempunyai peranan penting dalam merubah perilaku seseorang. Dalam hal ini, tersedianya dana kegiatan posyandu terutama untuk honor dan transportasi kader akan memotivasi kader lebih aktif lagi bekerja menggerakkan ibu balita ke posyandu.

Partisipasi

masyarakat

menimbulkan masalah tersendiri bagi posyandu, dikarenakan pengunjung posyandu amat kurang, penyebabnya ialah promosi, dan regenerasi posyandu yang kurang baik, serta ketersediaan dana yang kurang.

Oleh karena itu untuk menjalankan kegiatan posyandu, seharusnya tidak hanya mengandalkan dana dari pemerintah tapi juga peran serta dari masyarakat dengan mengadakan iuran wajib maupun arisan rutin masyarakat yang kemudian dana yang terkumpul dapat dimanfaatkan untuk honor kader sehingga dapat memotivasi kader dalam memotivasi ibu balita ke posyandu. Ketersediaan dana untuk PMT, pelatihan kader, pelatihan dan pemberian keterampilan kepada toma tentang posyandu juga akan mensukseskan program posyandu terutama dalam menggerakkan ibu balita ke posyandu.

\section{Metode}

Metode promkes untuk peningkatan kunjungan ibu balita ke posyandu di kedua puskesmas yaitu memberikan penyegaran kader dan penyediaan PMT. Wawancara ini didukung hasil pengamatan peneliti bahwa tidak ada PMT dan peran Toma kurang.

Di Puskesmas Lubuk Buaya, metode yang dilakukan dengan bekerjasama dengan distributor susu kedelai, buku pedoman dan pelatihan/keterampilan kepada toma dalam menggerakkan ibu balita ke posyandu. Petugas kesehatan dan kader langsung pada sore harinya melakukan pemantauan tumbuh kembang balita ke rumah-rumah ibu balita yang tidak berkunjung ke posyandu serta keahlian petugas promkes melakukan pendekatan kepada toma, tim penggerak PKK dalam menggerakkan posyandu.

Menurut Green dalam Notoatmodjo (2003), salah satu faktor pemungkin (enabling) yang mempunyai peranan penting untuk merubah perilaku yaitu keahlian petugas. Keahlian petugas adalah salah satu faktor yang mempunyai peranan penting dalam merubah perilaku ibu balita untuk membawa balitanya ke posyandu. Dalam hal ini, dengan adanya pemberian pelatihan kepada toma dan kader.

Metode yang kreatif dengan diikuti oleh peraturan yang baik, seharusnya menjadi dasar bahwa pentingnya aturan yang mengatur mengenai terlaksananya promkes dalam peningkatan kunjungan ibu balita ke posyandu. Tetapi pada kenyataannya aturan dan prosedur tetap tidak ada untuk dijadikan pedoman dalam mengontrol kegiatan promkes yang dilakukan karena sifatnya yang tidak mengikat secara kuat. Diperlukan aturan yang lengkap untuk penyelenggaraan promkes dalam peningkatan kunjungan ibu balita ke posyandu. Selain itu, petugas dan kader menyesuaikan tempat posyandu yang mudah untuk dijangkau oleh masyarakat dan waktu yang kondusif bagi masyarakat. Peran sosialisasi dan perencanaan yang strategis ini bisa memberikan informasi untuk setiap petugas dan instansi terkait sehingga dapat 
membuat perencanaan kedepannya untuk diajukan guna memperbaiki pelayanan kesehatan di posyandu dan meningkatkan kunjungan ibu balita ke posyandu.

\section{Sarana}

Hasil penelitian diketahui bahwa prasarana (masih adanya posyandu yang belum memiliki bangunan sendiri), dan sarana posyandu masih banyak yang tidak memadai seperti timbangan banyak yang tidak layak pakai karena sudah lama dan tidak dikalibrasi sehingga pengukurannya tidak valid. Pemanfaatan media informasi seperti papan informasi, brosur, leaflet tentang pentingnya posyandu belum ada sehingga ibu balita tidak tertarik datang ke posyandu.

Di Puskesmas Nanggalo, belum memiliki bangunan sendiri sehingga perlu adanya swadaya masyarakat untuk menyediakan bagunan posyandu dan secara bersama menciptakan lingkungan posyandu yang nyaman. Selain dari unsur bangunan, sarana timbangan juga perlu diperhatikan apabila banyak timbangan yang tidak layak pakai karena sudah lama dan tidak dikalibrasi sehingga pengukurannya tidak valid dapat menyebabkan penurunan minat dan kepercayaan masyarakat sehingga menurunkan tingkat kunjungan ke posyandu.

Sebaliknya di Puskesmas Lubuk Buaya, tempat penyelenggaraan posyandu sudah menetap di rumah warga, meja tidak ada yang rusak dan timbangan sudah dikalibrasi. Sudah tersedia papan informasi, sedangkan poster, dan leafleat tidak ada.

Fasilitas kesehatan merupakan sarana penting dimana dalam memberikan pelayanan kesehatan dan penyuluhan terhadap masyarakat. Fasilitas atau sarana kesehatan yang harus tersedia demi kenyamanan pelayanan yang diberikan kepada masyarakat, fasilitas penunjung untuk pelayanan yang diberikan dapat berupa fasilitas gedung pelayanan yang memadai dan dapat menimbulkan daya tarik, serta informasi kesehatan yang didapat baik cetak dan elektronik (Notoatmodjo, 2010).
Hasil penelitian ini sesuai dengan penelitian yang dilakukan oleh Sucipto (2009) yang menyatakan bahwa adanya sarana yang mendukung dalam promkes dapat berperan dalam peningkatan kunjungan ibu balita ke posyandu. Sarana dan prasarana yang ada dapat menarik minat ibu balita untuk datang ke posyandu dan memanfaatkan pelayanan kesehatan yang ada di posyandu.

Oleh karena itu untuk meningkatkan kunjungan ibu balita ke posyandu dalam melakukan penimbangan untuk bayi dan balita perlu juga adanya pemanfaatan media informasi seperti papan informasi, poster, brosur, leaflet dalam memberitahukan jadwal posyandu sehingga ibu balita tertarik datang ke posyandu dan memanfaatkan pelayanan yang ada di posyandu.

\section{Komponen Proses}

Komponen proses yang dibahas dalam penelitian ini meliputi advokasi, kemitraan, pemberdayaan masyarakat terhadap kunjungan ibu balita ke posyandu.

\subsection{Advokasi}

Hasil penelitian diketahui bahwa advokasi promkes dalam peningkatan kunjungan ibu balita ke posyandu. Advokasi dalam kegiatan promkes melibatkan lintas sektor terkait seperti toma, camat, lurah, tim penggerak PKK, dan kader. Namun peran serta mereka masih kurang dan belum merasa memiliki posyandu. Dalam pelaksanaannya hanya kader yang aktif. Bentuk peran kelurahan hanya sebatas mengkoordinir uang penggantian transport dari PNPM.

Advokasi akan lebih efektif bila dilaksanakan dengan prinsip kemitraan, yaitu dengan membentuk jejaring advokasi atau forum kerjasama. Pengembangan kemitraan adalah upaya membangun hubungan para mitra kerja berdasarkan kesetaraan, keterbukaan dan saling memberi manfaat. Sehingga advokasi, kemitraan berarti mempertahankan, berbicara serta mendukung seseorang untuk mempertahankan ide dan kerja sama dengan berbagai pihak (Maulana, 2009).

Advokasi di kedua Puskesmas dilakukan oleh Petugas Pemegang Program 
Promosi Kesehatan kepada Pimpinan Puskesmas dan Lurah di wilayah kerjanya. Toma tidak aktif dalam membantu pelaksanaaan kegiatan posyandu. Oleh karena itu perlu disusun suatu kebijakan/petunjuk teknis yang menyatakan bahwa posyandu dibawah tanggung jawab dari kecamatan dan kelurahan sehingga camat dan lurah memiliki tanggung jawab dan tugas pokok serta fungsi.

\subsection{Kemitraan}

Kemitraan yang dilakukan di Puskesmas Nanggalo bahwa petugas pemegang promkes menjalin kemitraan dengan kader, toma, tim penggerak PKK. Berdasarkan hasil wawancara, observasi san telaah dokumen ditemukan bahwa hanya kader yang aktif bekerja. Kemitraan yang dilakukan oleh petugas kesehatan dapat ditingkatkan dengan membekali petugas buku pedoman. Sedangkan di Puskesmas Lubuk Buaya, petugas promkes menjalin kerjasama dengan kader, toma, tim penggerak PKK, dan lurah. Semua yang terlibat tersebut aktif bekerja memotivasi ibu balita ke posyandu dan menggerakkan posyandu dengan menumbuhkan kesadaran ibu balita pentingnya membawa balita ke posyandu mendapatkan pelayanan untuk memantau tumbuh kembang balitanya.

Hal ini didukung dengan hasil penelitian Sucipto (2009) yang menyatakan bahwa adanya bina suasana dalam promosi kesehatan dapat berperan dalam praktik peningkatan kunjungan ibu balita ke posyandu. Adanya kemitraan yang terbentuk dapat mendorong masyarakat untuk memanfaatkan pelayanan posyandu terutama melakukan penimbangan untuk balita agar dapat memantau tumbuh kembangnya.

$$
\text { Menurut Green dalam }
$$

Notoatmodjo (2007), salah satu faktor pemungkin (enabling) yang mempunyai peranan penting untuk merubah perilaku yaitu tersedianya keterampilan petugas. keterampilan petugas adalah salah satu faktor yang mempunyai peranan penting dalam merubah perilaku seseorang. Dalam hal ini, keterampilan petugas kesehatan menjalin kerjasama baik dalam bentuk member dukungan kepada Toma, tim penggerak PKK dan Lurah dapat memotivasi untuk mensukseskan program posyandu terutama menggerakkan ibu balita ke posyandu.

Dengan kegiatan dimana petugas kesehatan dapat mencari dukungan sosial melalui Toma yang pada dasarnya adalah mensosialisasikan program-program kesehatan, agar masyarakat mau menerima dan mau berpartisipasi dalam program kesehatan tersebut. Oleh sebab itu, strategi tersebut dapat dikatakan sebagai upaya bina suasana, atau membina suasana yang kondusif terhadap kesehatan. Bentuk kegiatan kemitraan yang dapat dilakukan antara lain: pelatihan pelatihan para TOMA, seminar, lokakarya, bimbingan kepada TOMA dan sebagainya. Dengan demikian maka sasaran utama dukungan sosial atau kemitraan adalah para tokoh masyarakat di berbagai tingkat baik kecamatan maupun kelurahan.

\subsection{Gerakan Pemberdayaan Masyarakat} Hasil penelitian di Puskesmas Nanggalo diketahui bahwa gerakan pemberdayaan masyarakat dalam promkes untuk peningkatan kunjungan ibu balita ke posyandu masih kurang. Dalam pelaksanaannya hanya kader yang berperan, salah satu contohnya kader aktif dalam melakukan sweeping untuk mendatangi rumah ibu balita yang tidak datang ke posyandu yaitu dengan mengunjunginya di waktu sore hari. Peran toma,tim penggerak PKK, kader, dan lurah kurang dalam menggerakkan posyandu. Inisiatif masyarakat dan kader kurang mengumpulkan dana PMT secara swadaya. Padahal adanya PMT sangat menarik untuk memotivasi ibu balita ke posyandu. Masyarakat kurang paham bahwa posyandu adalah UKBM yang merupakan usaha kesehatan dari masyarakat oleh masyarakat dan untuk masyarakat sendiri sedangkan petugas kesehatan hanya menjembatani/memfasilitasi kegiatan posyandu.

Di Puskesmas Lubuk Buaya, masyarakat khususnya ibu balita sudah memahami pentingnya posyandu dan menyadari posyandu adalah milik masyarakat dan untuk masyarakat sendiri. 
Kader, toma, tim penggerak PKK dan lurah aktif melakukan kegiatan promosi kesehatan untuk menggerakkan posyandu sehingga posyandu setiap bulannya ramai didatangi ibu balita. Berdasarkan pengamatan peneliti bahwa tidak semua posyandu kurang dalam pemberdayaan, terdapat juga masyarakat aktif dalam pengadaan PMT yang didapatkan dari arisan, kader menghimpun dana sukarela dari masyarakat, donator di RW setempat.

Berdasarkan hasil wawancara peneliti dengan 6 orang ibu balita di wilayah kerja Puskesmas Nanggalo dan 7 orang ibu balita di wilayah kerja Puskesmas Lubuk Buaya bahwa kader aktif bekerja menginformasikan jadwal posyandu sebelum hari pelaksanaan posyandu dan melakukan penyuluhan bersama petugas kesehatan, memantau tumbuh kembang balita, dan melakukan sweeping ke rumah-rumah pada sore hari apabila ibu balita tidak datang ke posyandu.

Berdasarkan hasil wawancara peneliti dengan 2 orang kader di wilayah kerja Puskesmas Nanggalo dan 4 orang kader di wilayah kerja Puskesmas Lubuk Buaya bahwa dari 6 orang kader yang diwawancarai, semua kader aktif bekerja secara sukarela karena posyandu adalah milik masyarakat, oleh masyarakat dan untuk masyarakat sendiri. Kader dibantu Pemegang promkes puskesmas dan Pustu. Lurah, PKK dan Toma kurang aktif menggerakkan posyandu.

Hasil penelitian ini sesuai dengan penelitian yang dilakukan oleh Sucipto (2009), yang menyatakan bahwa adanya gerakan pemberdayaan masyarakat untuk mendukung promkes dapat berperan dalam peningkatan kunjungan ibu balita ke posyandu.

Menurut Maulana (2009), pemberdayaan adalah strategi promkes yang ditujukan pada masyarakat langsung. Tujuan utama pemberdayaan adalah mewujudkan kemampuan masyarakat dalam memelihara dan meningkatkan kesehatan mereka sendiri (visi promosi kesehatan).

Bentuk kegiatan pemberdayaan ini dapat diwujudkan dengan berbagai kegiatan, antara lain: penyuluhan kesehatan, pengorganisasian dan pengembangan masyarakat dalam bentuk misalnya: koperasi, pelatihan-pelatihan untuk kemampuan peningkatan pendapatan keluarga (income generating skill). Dengan meningkatnya kemampuan ekonomi keluarga akan berdampak terhadap kemampuan dalam pemeliharaan kesehatan mereka, misalnya terbentuknya dana sehat untuk kegiatan posyandu, berdirinya bangunan posyandu yang permanen, dan sebagainya. Kegiatankegiatan semacam ini di masyarakat sering disebut "gerakan masyarakat" untuk kesehatan.

\subsection{Output}

Hasil penelitian diketahui bahwa output promosi kesehatan dalam peningkatan kunjungan ibu balita di Puskesmas Nanggalo masih rendah sedangkan di Puskesmas Lubuk Buaya sudah baik tetapi masih dibawah target nasional . Promosi kesehatan dilakukan oleh petugas dan dibantu oleh kader. Faktanya masih terdapat posyandu dengan tingkat kunjungan ibu balita yang masih rendah. Hal ini disebabkan oleh berbagai hambatan diantaranya fasilitas posyandu yang tidak memadai (bangunan dan media edukasi di posyandu), masih terdapat kader yang tidak aktif, peran serta toma kurang aktif, dan insentif untuk kader kurang.

Untuk meningkatkan kunjungan ibu balita perlu dilakukan beberapa inisiatif diantaranya puskesmas harus memiliki kohort balita sendiri untuk memantau balita yang sudah mendapatkan pelayanan di posyandu, selain daripada itu daya tarik posyandu berupa fisik bangunan yang memadai dan dilengkapi fasilitas juga menjadi hal yang penting dalam peningkatan partisipasi ibu balita, swadaya masyarakat dalam hal mendukung kegiatan posyandu juga perlu dilakukan dengan membentuk arisan warga demi membantu pelaksanaan kegiatan posyandu contohnya PMT.

Hasil penelitian diketahui bahwa pelaksanaan promkes dalam peningkatan kunjungan ibu balita ke posyandu di Puskesmas Nanggalo kurang baik, disebabkan karena koordinasi lintas program dan lintas sektor, dukungan dana 
yang kurang, metode penyuluhan kurang menarik dan sarana posyandu kurang. Kurangnya kerjasama lintas sektor dan angka statistik untuk target balita ditimbang dengan perbandingan jumlah balita di wilayah kerja sangat tinggi, dan kurangnya frekuensi penyuluhan yang dilakukan oleh petugas kesehatan tentang pentingnya penimbangan posyandu, serta peran kader masih kurang memotivasi ibu balita ke posyandu.

Sebaliknya di Puskesmas Lubuk Buaya Kota Padang sudah baik, dimana petugas promkes memasukkan data setiap bulannya (tanggal 5) melaporkan pencapaian tingkat kunjungan ibu balita ke posyandu dan pemegang program promkes melaporkan kepada pimpinan puskesmas dan pada lokakarya mini diberikan pemecahannya dan dibicarakan bersama. Untuk kader yang tidak aktif petugas promosi kesehatan mencarikan penggantinya dan digantikan.

Oleh karena itu, dibutuhkan kerjasama lintas sektor terkait yang komprehensif dengan melibatkannya baik dalam hal perencanaan maupun penyusunan kegiatan sehingga merasa dilibatkan, selain daripada itu perlu adanya revisi target balita yang ditimbang dan disesuaikan dengan jumlah balita yang ada di wilayah kerja puskesmas melalui pendataan kembali jumlah balita.

Dalam menunjang pelaksanaan promkes perlu meningkatkan frekuensi penyuluhan yang dilakukan oleh petugas untuk memberikan informasi mengenai pentingnya membawa balita ke posyandu guna memantau tumbuh kembang balita. Selain daripada itu dengan adanya kader sebagai petugas yang berada pada jejaring terdekat di masyarakat perlu diperhatikan insentif dan penghargaan yang diberikan sehingga dapat memotivasi kader dalam bertugas dan dapat memotivasi ibu balita ke posyandu.

\section{KESIMPULAN}

Hasil penelitian Pelaksanaan Promosi Kesehatan dengan Kunjungan Ibu Balita ke Posyandu diketahui Di Puskesmas Nanggalo dan Puskesmas Lubuk Buaya didapatkan belum ada petunjuk teknis, sumber dana dari Anggaran Pendapatan Belanja Daerah (APBD) dan Biaya Operasional Kesehatan (BOK). Di Puskesmas Nanggalo, petugas promkes sebagai pelaksana posyandu, sedangkan di Puskesmas Lubuk Buaya petugas promkes sebagai pengkoordinir kegiatan. Prasarana (tempat posyandu menumpang di rumah warga atau mesjid) dan sarana (timbangan belum dikalibrasi serta poster, leafleat, PMT) tidak ada di Puskesmas Nanggalo sedangkan di Puskesmas Lubuk Buaya prasarana menetap di rumah warga dan sarana seperti di atas sudah tersedia di posyandu. Kemitraan dan pemberdayaan Puskesmas Lubuk Buaya berjalan dengan baik dibandingkan Puskesmas Nanggalo sehingga tingkat kunjungan ibu balita hampir mencapai target.

\section{DAFTAR PUSTAKA}

Azwar, A. 1996. Pengantar Administrasi Kesehatan. Edisi ke tiga. Bina Pura Aksara. Jakarta.

Bachtiar, A. 2000. Metode Penelitian Kesehatan, Program Pasca Sarjana Program Studi Ilmu Kesehatan Masyarakat, UI, Jakarta.

Dinkes Prov Sumbar. 2012. Laporan Tahunan Dinas Kesehatan Kota Padang. Dinas Kesehatan Provinsi.

2013. Kebijakan

Pemantauan Pertumbuhan dan Perkembangan Anak Usia Dini di Bidang Kesehatan. Model Integrasi Posyandu, PAUD, BKB di Padang.

Depkes RI. 2006. Pedoman Umum Pengelolaan Posyandu. Rineka Cipta. Jakarta.

2006. Panduan Integrasi Promosi Kesehatan. Pusat Promkes Depkes RI. Jakarta. 2008. Pedoman Umum Pengelolaan Posyandu. Rineka Cipta. Jakarta. 2008. Modul Kesehatan Bagi Tenaga Promosi Kesehatan di Puskesmas. Jakarta. 2011.

Rencana Pengembangan Tenaga Kesehatan Tahun 2011-2025. Jakarta. 
Dinkes Kota Padang. 2013. Laporan Tahunan Promosi Kesehatan Tahun 2013. Dinas Kesehatan Kota Padang.

Gurning, F. P., Pratama, M. Y., E., Ratodi, M., \& P. 2018. The Exclusive Breastfeeding Policies Implementation and Health Workers Roles in MedanIndonesia.http://doi.org/10.17605/ OSF.IO/9F7X3

Gurning, F.P. 2017. Pembinaan Puskesmas Terhadap Pelaksanaan Program Usaha Kesehatan Sekolah Di Wilayah Kerja Puskesmas Padang Matinggi Kota Padangsidimpuan. Jurnal Ilmiah Penelitian Kesehatan (Jumantik).http://jurnal.uinsu.ac.id/ index.php/kesmas/article/view/119 0 Tanggal Akses 28 Desember 2017.

Gurning, F.P. 2017. Pengaruh Karakteristik Kader Terhadap Keaktifan Kader Posyandu Di Desa Bahung Sibatu-Batu Kecamatan Sei Dadap Kabupaten Asahan. Jurnal Ilmiah Penelitian Kesehatan (Jumantik). http://jurnal.uinsu.ac.id/index.php/ kesmas/article/view/1191 Tanggal Akses 28 Desember 2017.

Hasibuan, M.S.P. 2007. Organisasi dan Motivasi Dasar Peningkatan Produktivitas Cetakan Kelima. Budi Aksara. Jakarta.

Heriyani, F. 2010. Hubungan Pendidikan, Pekerjaan, Pengetahuan, dan Kepuasan Ibu Terhadap Posyandu dengan Frekuensi Kunjungan Balita ke Posyandu di Puskesmas Tahun 2010. (Fakultas Kedokteran, Universitas Lambung Mangkurat.

Kemenkes RI. 2010. Rencana Operasional Promosi Kesehatan Ibu dan Anak. Jakarta.

\footnotetext{
- 2011. Promosi Kesehatan di Daerah Bermasalah Kesehatan, Pantuan Bagi Petugas Kesehatan di Puskesmas. Jakarta.

- . 2013. Riset Kesehatan Dasar Tahun 2013. Jakarta.
— 2013. Laporan Kinerja Kegiatan Pembinaan Gizi Menuju

Perbaikan Gizi Perseorangan dan Masyarakat yang Bermutu Tahun 2011. Direktorat Jenderal Bina Gizi dan Kesehatan Ibu dan Anak Direktorat Bina Gizi. Jakarta. 2011. Pedoman Pengelolaan Posyandu. Jakarta.

Laporan Tahunan Program Promosi Kesehatan Puskesmas Nanggalo Kota Padang. Tahun 2013 2013. Puskesmas Lubuk Buaya Kota Padang. Tahun 2013. Laporan Tahunan Puskesmas Nanggalo Kota Padang. Tahun 2013

Puskesmas Lubuk Buaya Kota Padang. Tahun 2013.

Notoatmodjo, S. 2007. Promosi Kesehatan dan Ilmu Perilaku. Rineka Cipta. Jakarta.

2003. Kesehatan Masyarakat (Ilmu dan Seni). PT Rineka Cipta. Jakarta.

Pratiwi, N.L. Penilaian Peran Serta Masyarakat dalam Akselerasi Penurunan Angka Kematian Ibu dan Angka Kematian Bayi. Puslitbang Sistem Kebijakan Kesehatan. (Vol. 23, No. 2, Hal. 89-95, Juni 2007). Surabaya, Jawa Timur.

Putra. 2013. Metode Penelitian Kualitatif Manajemen. PT. RajaGrafindo Persada. Jakarta.

Simamora, A.C. 2010. Pengaruh Pengetahuan Petugas Kesehatan Terhadap Pelaksanaan Program Promosi Kesehatan di Puskesmas Kabupaten Humbang Hasundutan Tahun 2010 (Tesis). Program Studi S2 Ilmu Kesehatan Masyarakat FKM USU. Medan.

Sugiyono. 2010. Metode Penelitian Kuantitatif Kualitatif. Alfabeta. Bandung.

Trihono. 2005. Arrimes Manajemen Puskesmas Berbasis Paradigma Sehat. CV. Sagung Seto. Jakarta.

Tando, N. M. 2013. Organisasi dan Manajemen Pelayanan Kesehatan. In Media. Jakarta. 